\title{
The geotourist attractions in the vicinity of Szczawnica spa
}

\author{
Jan Golonka ${ }^{1}$, Anna Waśkowska ${ }^{1}$, Marek Doktor ${ }^{1}$, Michał Krobicki ${ }^{1,2}$, Tadeusz Słomka ${ }^{1}$ \\ ${ }^{\prime}$ AGH University of Science and Technology, Faculty of Geology, Geophysics and Environmental Protection, \\ Department of General Geology and Geotourism; al. Mickiewicza 30, 30-059 Kraków; \\ e-mail:jgolonka@agh.edu.pl; waskowsk@agh.edu.pl; krobicki@geol.agh.edu.pl; \\ michal.krobicki@pgi.gov.pl;doktor@agh.edu.pl;tslomka@agh.du.pl \\ ${ }^{2}$ Polish Geological Institute - National Research Institute, Carpathian Branch, ul. Skrzatów 1, 31-560 Kraków
}
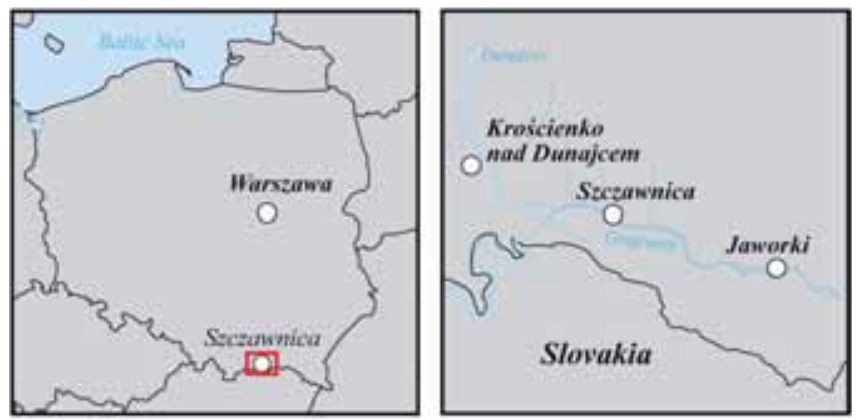

Abstract: The main aim of this paper is presentation of the most characteristic outcrops/geological monuments, which occur in Szczawnica spa vicinity and are perfect geotouristic objects. These objects are presented with short geological/geomorphological remarks about their origin, development and significance in natural sciences. They provide the excellent inanimate natural monuments (geotourist trail in Pieniny Mountains from Szczawnica to Červený Kláštor, Palenica Mountain, Zawiasy area, Bryjarka Mountain, Jarmuta Mountain and Zaskalnik Waterfall), which can be used for better understanding of the history of our Earth and numerous geological processes, which ,sculptured” its surface, especially very complicated geological story of the Pieniny Klippen Belt.

Key words: geotourism, Szczawnica spa, Pieniny Klippen Belt, Beskid Sądecki Mts, geotouristic objects

\section{Introduction}

The name Szczawnica was mentioned in $13^{\text {th }}$ century documents. The Kraków duke, Bolesław Wstydliwy gave this area to his wife, saint Kinga, patron of the Pieniny region (Węglarz, 2011). The Szczawnica mineral waters were known already in medieval times (e.g., Golonka, 2006; Golonka, Krobicki, 2007; Golonka et al., 2014; and papers cited therein). The town's name was derived from word szczawa (Fig. 1), water with carbon dioxide. Since $16^{\text {th }}$ the mineral water were known and used as medical treatment. The spa was developed during XIX century by the Szalay family. The oldest known springs Stefan and Józefina were named after the member of this family. Józef Szalay developed the modern health resort in the second half of XIX century. Józef Dietl, the president of Kraków and famous balneologist also contributed to the spa development. Today Szczawnica is a famous destination for thousands of patients, vacationers and tourists. They admire the XIXth century architecture monument, splendid parks and beautiful surroundings (Fig. 2).
The aim of this paper is to turn attention into geotourist attractions located in these surroundings. The town is situated between Beskid Sądecki and Małe Pieniny mountain ranges and close to the Pieniny Mountains with their famous Dunajec River Gorge. The mineral waters originated due to the circulation within cracks in the flysch rocks of the Magura Nappe, which build the Beskid Sądecki mountain range with peaks Dzwonkówka (990 m asl), Skałka (1163 m asl), Przehyba (1175 m asl), Złomisty Wierch (1181 m asl) and Radziejowa (1262 m asl). The Małe Pieniny Mountains are located south-east of the spa. They are easily reached by the chair lift to the Palenica Mountain (722 m asl) known for excellent ski and mountain bike trails (e.g., Golonka, 2006; Golonka, Krobicki, 2007; Słomka ed., 2012; Golonka et al., 2014; and papers cited therein).

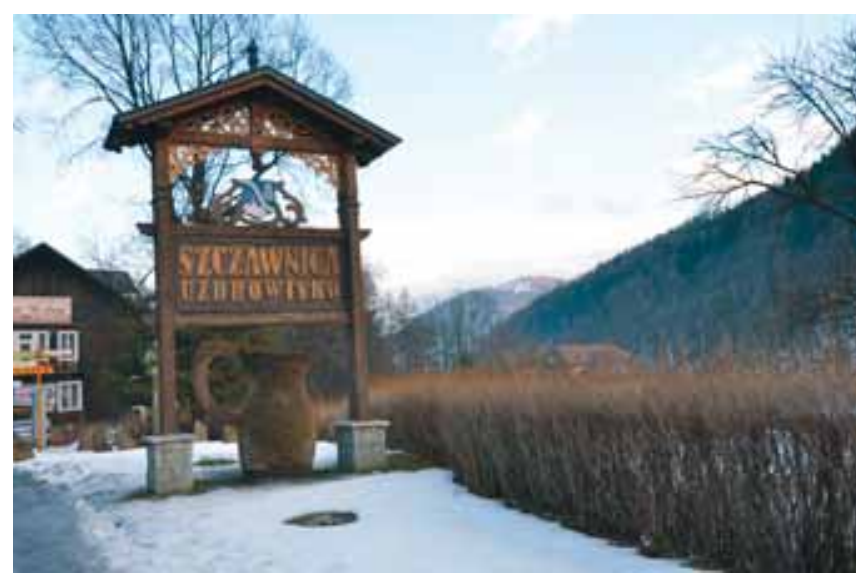

Fig. 1. Entrance to the Szczawnica town, photo M. Doktor

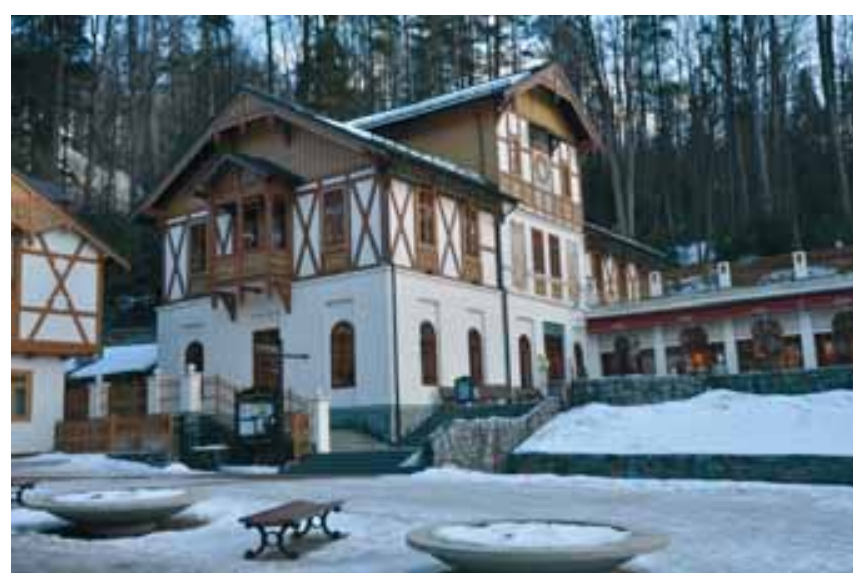

Fig. 2. Typical spa architecture in Szczawnica, photo M. Doktor 


\section{Geological setting}

The Pieniny Klippen Belt forms northern limit of Inner Carpathians in Poland. Its 40 kilometer long Polish part is entirely located within Małopolska province. It is almost entirely built of sedimentary rocks: limestones, siliceous and clastic rocks, which were deposited in oceanic type basin (Birkenmajer, 1977, 1979). This basin forms the extension of Atlantic Ocean 200-180 million years ago (Early Jurassic time) and is known as Alpine Tethys Ocean. The extremely complex tectonic evolution led to the origin of narrow, elongated structure. The name Klippen Belt is derived from the cliffs (German Klippen), being harder, and more erosion resistant elements placed (mainly Jurassic-Lower Cretaceous), like raisins in dough within less competent clastic deposits: sandstones, shales and marls (mainly Cretaceous-Paleogene). The sandstones and shales form the alternating layers building flysch complexes. These cliffs often belong to olistoliths that is different in size rock complexes, which slipped from the uplifted areas to the deeper flysch basins. The other cliffs were placed in the clastic rocks as a result of tectonic processes. The Pieniny Klippen Belt originated 20 to 14 million years ago (during Miocene time) as flower structure limited on both sides by the deeply rooted faults. Following its uplift, the Pieniny Klippen Belt obtain its present structure, which removed less competent rock complexes, leaving harder cliffs protruding and well visible against their background (Słomka, ed., 2012).

The Beskid Sądecki mountain range belongs to the Outer Carpathians, which are built up of a stack of nappes and thrust sheets formed by to six kilometers thick continual flysch sequences, representing the time span from Jurassic to Early Miocene. These nappes were thrust over the North European Platform. During overthrusting movement the northern Carpathians nappes became uprooted from the basement and only their basinal parts were preserved (Ślączka et al., 2006). The succession of the nappes from north to south is as follows: Skole (Skiba) Nappe (mainly easternmost part of the Carpathians), Subsilesian Nappe, Silesian Nappe, Fore-Magura group of nappes and Magura Nappe. The Magura Nappe, which forms the Beskid Sądecki Mountains, is the largest tectonic unit of the Western Carpathians. It is divided into four facies-tectonic subunits: the Krynica, Bystrica, Rača and Siary (Ślączka et al., 2006 and papers cited therein). The rocks of the Magura Nappe were deposited within the Magura Basin, which existed from Jurassic to Miocene time as a part of the western Alpine Tethys Ocean. Part of the Magura Basin deposits was incorporated into the tectonic structure of the Pieniny Klippen Belt and part belongs to the Krynica subunit of the Magura Nappe. The Magura Nappe is separated from the Pieniny Klippen Belt in this area by dipping steeply southward strike-slip boundary (Ślączka et al., 2006 and papers cited therein). The Krynica subunit includes the uppermost Cretaceous-Oligocene flysch rocks in the area adjacent to the Pieniny Klippen Belt in Poland. The older, Jurassic-Cretaceous deposits, are known only from the olistoliths within the flysch (Cieszkowski et al., 2009; Golonka et al., 2010, 2015 and papers cited therein).

The flysch deposits of the Krynica subunit in the Szczawnica area belong to the Paleocene-Lower Eocene Szczawnica Formation, Eocene Zarzecze Formation and Eocene-Oligocene
Magura Formation. The inverse geomorphology is typical for the Beskid Sądecki Mountains. The mountain tops are built of synclines. The Dzwonkówka-Radziejowa mountain range south of Szczawnica belongs to the large the syncline with the Magura Formation deposits. The deposits of the Szczawnica or Zarzecze formations, less resistant to erosion, forming anticlines occur on the slopes and within the valleys (Chrustek et al., 2005).

The flysch units of the Magura Nappe and the Pieniny Klippen Belt are cut by the intrusions of magmatic, subvolcanous rocks, known as andesites. They occur in the Szczawnica area in Bryjarka (Beskid Sądecki mountain range) and Jarmuta (Małe Pieniny Mountains). They were formed during the Neogene times (Birkenmajer et al., 1987). They perhaps contributed to the origin of the Szczawnica mineral waters.

\section{Trans-border (Polish-Slovakian) Pieniny Geopark}

The Szczawnica spa is situated within the limits of the proposed cross-border Polish-Slovakian geopark Pieniny. This geopark includes the central, most interesting part of the Pieniny Klippen Belt and the adjacent areas of the Central Carpathian Paleogene and Magura Nappe of the Outer Carpathians. Its core belongs to the Polish Pieniny National Park (Pieniński Park Narodowy) and its Slovak equivalent the Pieninský Narodný Park. The primary task in the framework of Geopark project will be an inventory and valorization of geosites. The Pieniny Geopark covers the area of Pieniny, Little (Małe) Pieniny, Spisian Pieniny, Podhale, Ljubovnianska Pahorkatina and Oravska Magura (Golonka et al., 2015).

Tourists can admire in this area an excellent illustration of the various processes of physical geology. It is possible to study the history of geological research and mining, rock and mineral resources, mineral waters elements of mineralogy and petrography, and the use of stone in architecture. Some of this geosites are located within the Szczawnica town limits and in its vicinity (Golonka et al., 2014).

\section{Selected geotouristic atractions}

\section{Geotourist trail in Pieniny Mountains from Szczawnica, Poland to Červený Kláštor, Slovakia}

This trail was built by Józef Szalay and established at the end of the XIX century. It became widely open for tourist traffic after May 2004, when Poland and Slovakia joined the European Union. Today it is the perfect example of the international cooperation as well as one of the most popular mountain trails in Poland and Slovakia, visited by millions of tourist since its establishment. During the sunny summer weekend day it is quite crowded by hikers and tourists on mountain bikes. The trail is very scenic, at the same time allowing seeing well exposed geology of the Pieniny Klippen Belt (Golonka et al., 2005). This trail starts at the boat harbor in Szczawnica $100 \mathrm{~m}$ from the main road Kraków-Szczawnica. Many restaurants and boots offering food and souvenirs are located here. The bikes for rent are also available. 


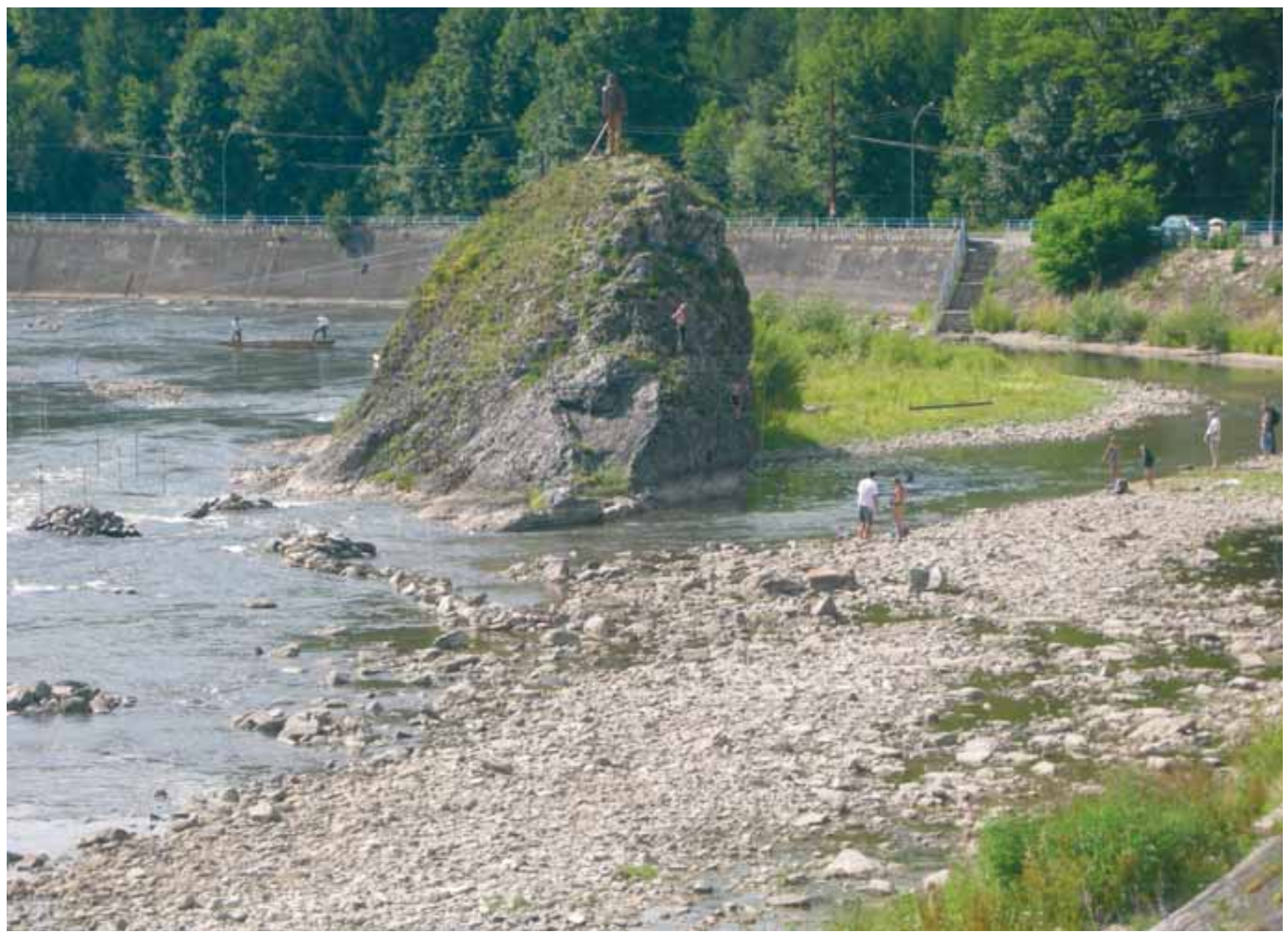

Fig. 3. Kotuńka klippe in the Dunajec riverbed, photo A. Waśkowska

Fig. 4. The Pieniny Limestone Formation (=Maiolica facies) in the Dunajec River valley, photo J. Golonka

Close to the harbor and clearly visible from the main way is the most recognizable rock of Szczawnica, called Kotuńka klippe (Fig. 3). It is located directly in Dunajec riverbed, now on the right bank. For the years the Kontuńka klippe formed an island in the middle of the Dunajec River, present position on the land due the change of the riverbed. This is $9,5 \mathrm{~m}$ high rock built of red nodular limestones (so-called Ammonitico Rosso facies) of the Czorsztyn Limestone Formation (Upper Jurassic in age) and white Calpionella-bearing limestones of the Dursztyn Limestone Formation (the uppermost Jurassic-lowermost Cretaceous) of the Czertezik Succession (Birkenmajer, 2007). Kotuńka klippe present probably one from many olistoliths within the flysch succession (Golonka et al., 2015). According to the local legend, this rock was dropped by a devil directly to the river. The wooden sculpture of a highlander, which used to stand on the top of Kotuńka was burned by a lightning during the thunderstorm in 2005. Outstretched hand of this highlander indicates the direction of the North.

The route is following the Pieniny Road along right bank of the river. The trail passes the mountain hotel „Orlica"; the first outcrops of the Pieniny Klippen Belt rocks could be examined here (comp. Birkenmajer, 1979). The Jurassic-Cretaceous deposits are strongly folded (Fig. 4).

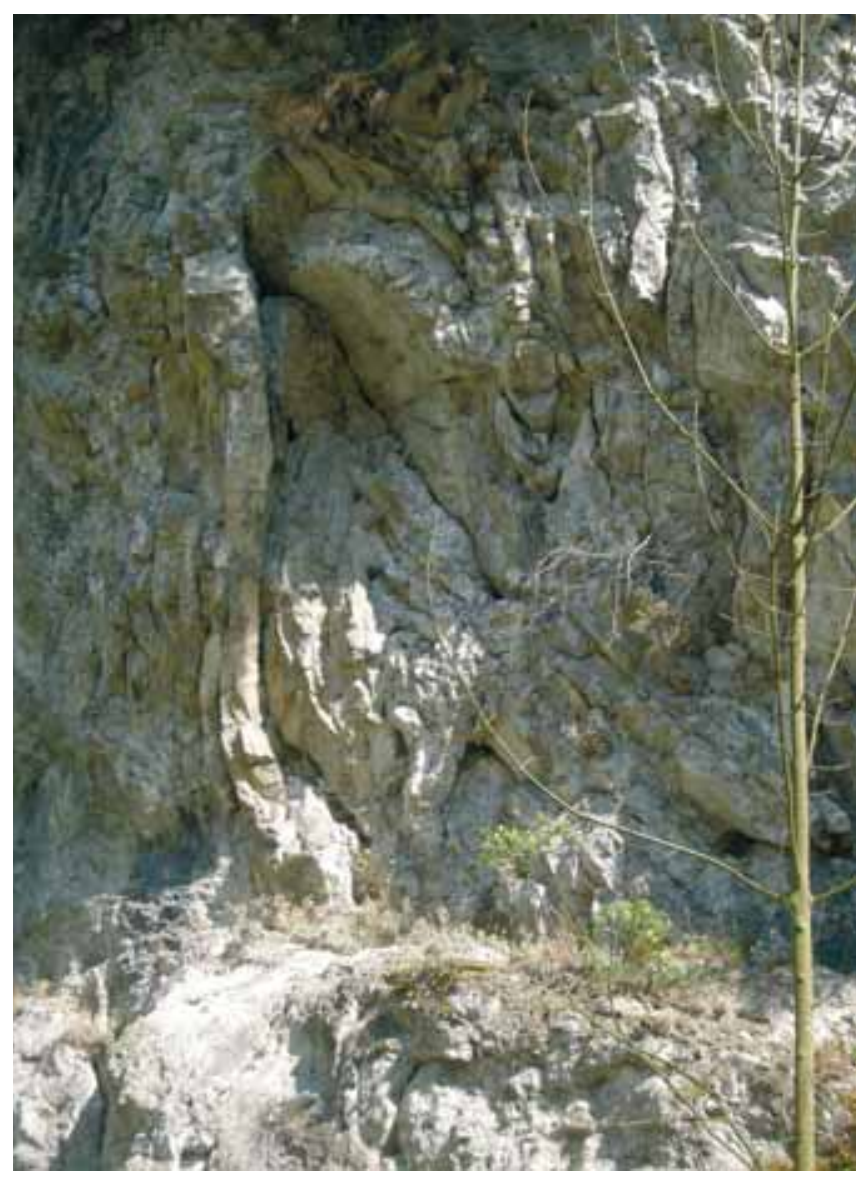




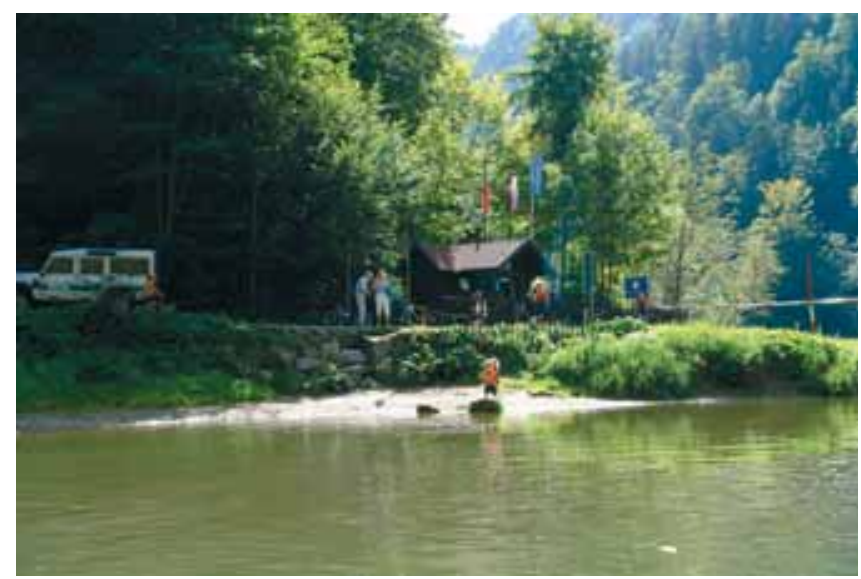

Fig. 5. The check-point on the Polish-Slovak border, photo J. Golonka

The more competent Upper Jurassic-Lower Cretaceous cherty limestones of the Pieniny Limestone Formation (socalled Maiolica facies, wide-spread type of limestones along all Alpine system in Europe) are constructed of tiny (below $0.01 \mathrm{~mm}$ size) planktonic algae Nannoconus and radiolaria. The cherty limestones are surrounded by less competent Lower and Upper Cretaceous marls, sandstones and shales. All these rocks were deposited in the deep oceanic-type basins. Limestones and marls represent pelagic type of sedimentation, while sandstones and shales flysch deposited by turbiditic currents. The karst processes sculptured the natural cave within the cherty limestones. The trail reaches the boundary of the Polish Pieniny National Park. Certain restrictions are imposed by the Park management, among the others the rock hammering and rock samples collection is not allowed here. The Park exhibition inform tourist about the Pieniny Mountains especially their plants and animal life (Tłuczek, 2004). $1 \mathrm{~km}$ from the trailhead is the ferry harbor. The ferry carries tourists wishing to hike the Sokolica Mountain and the Pieniny Mountains ridge.

One and half kilometer from the trailhead the trail crosses the Polish-Slovak border, the checkpoint before the implementation of the Schengen agreement in 2007 (Fig. 5). The route enters the Dunajec River Gorge - the most beautiful part of the Pieniny Mountains (Birkenmajer, 2006) (Fig. 6). The Hukowa Skała (Bang Rock) is the place where XIX century tourists traveling on boat announced they arrival by the gunfire. Further up the river, Sokolica Mountain (Falcon's Mountain) (747 m asl) constitutes one of the most beautiful Pieniny peaks (Fig. 7). Southern cliffs of the mountain built of rigid cherty limestones almost vertically reach the Dunajec River (Tłuczek, 2004). Across Sokolica group on the Slovak side two rocks Sama Jedna (Lone or Spinster Rock) and Wylizana (Licked Rock) frame the scenic gorge of Leśnica River (Fig. 8). The Pieniny Road runs along the Slovak bank of the river passing many cherty limestone cliffs, woods and meadows. The Dunajec River is winding frequently, the very sharp bend $\left(145^{\circ}\right)$ forms the large peninsula - Facimiech Mountain built of the Pieniny Limestone Formation surrounded by Dunajec.

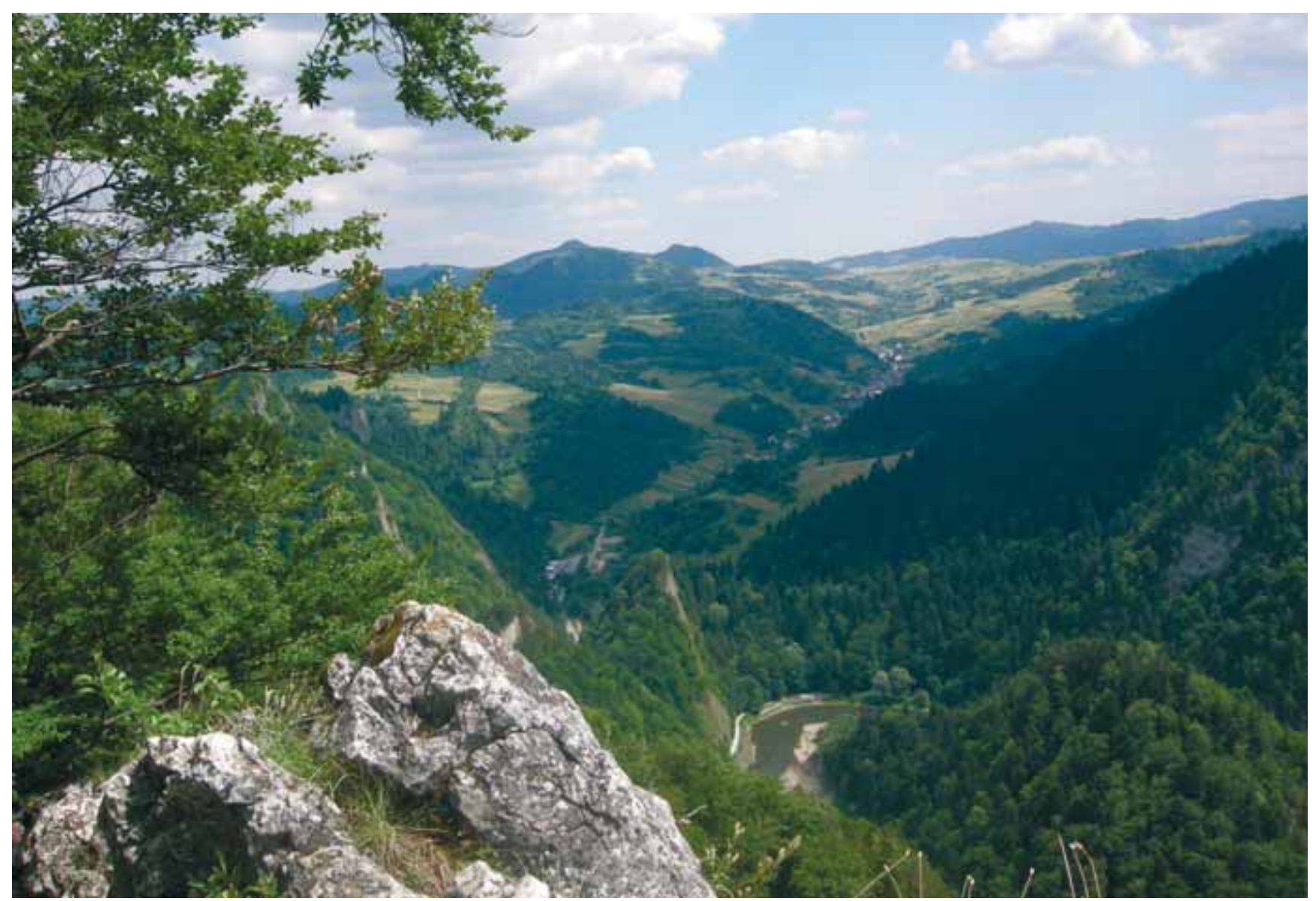

Fig. 6. The Dunajec River Gorge - view from the Sokolica Mountain, photo A. Waśkowska 
These bends originated during the ancient meandering stage of the river preceding the uplift of Pieniny Mountains and origin of the gorge. The karsts processes sculptured the limestones into shapes resembling the Polish Eagle and a nun. The scenic rocks known as Siedem Mnichów (Seven Monks) according to highland legends are monks from Červený Kláštor (Czerwony Klasztor, the Red Monastery) (Fig. 9) sneaking once toward the nun from Facimiech and turned into stones (Tłuczek, 2004). Ten kilometers from the trailhead the Sromowce Niżne village on the Polish side is located below the magnificent limestone walls of Trzy Korony (Three Crowns) Mountain (982 m asl), the highest mountain group of the Pieniny Mountains (Fig. 9). The Red Monastery was constructed on the Slovak side in XIV century and remodeled in XVIII century by Camelot order.

The origin of the Dunajec River Gorge is related to the neotectonic movements during the Neogene time and the most probably have been connected with antecedent type of origin of this gorge (Birkenmajer, 1979, 2006). Following the Serravalian formation of the Outer Carpathian fold-and-thrust belt the area at the plate boundary were covered during the Neogene by at least $600-900 \mathrm{~m}$ of sand, silt and clay, which were deposited in the Orava-NowyTarg Depression east of the Gorge (Chrustek, Golonka, 2005). The Dunajec River valley reached the mature stage during the latest Miocene-Pliocene time. This stage is indicated by the numerous meandering bends of the river. The vertical uplift of the Pieniny Mountains followed the meandering stage of Dunajec.

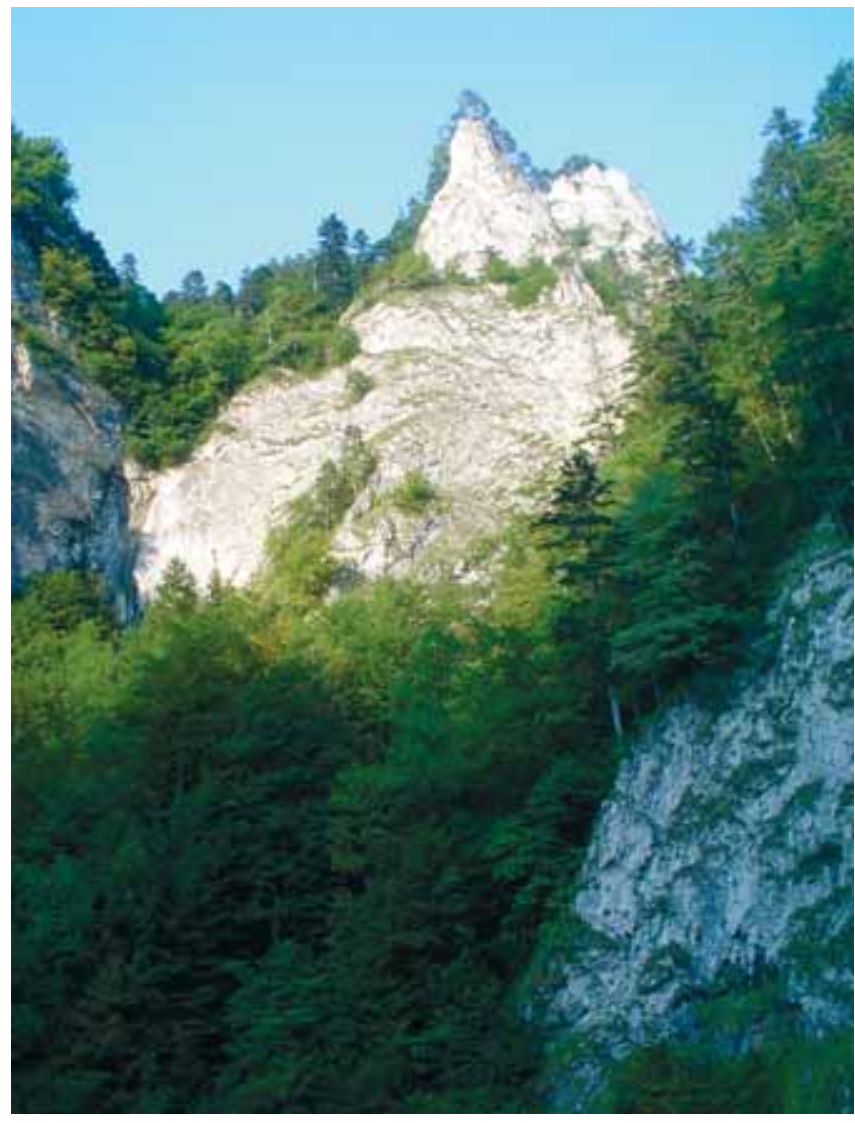

Fig. 7. The Sokolica peak, photo J. Golonka

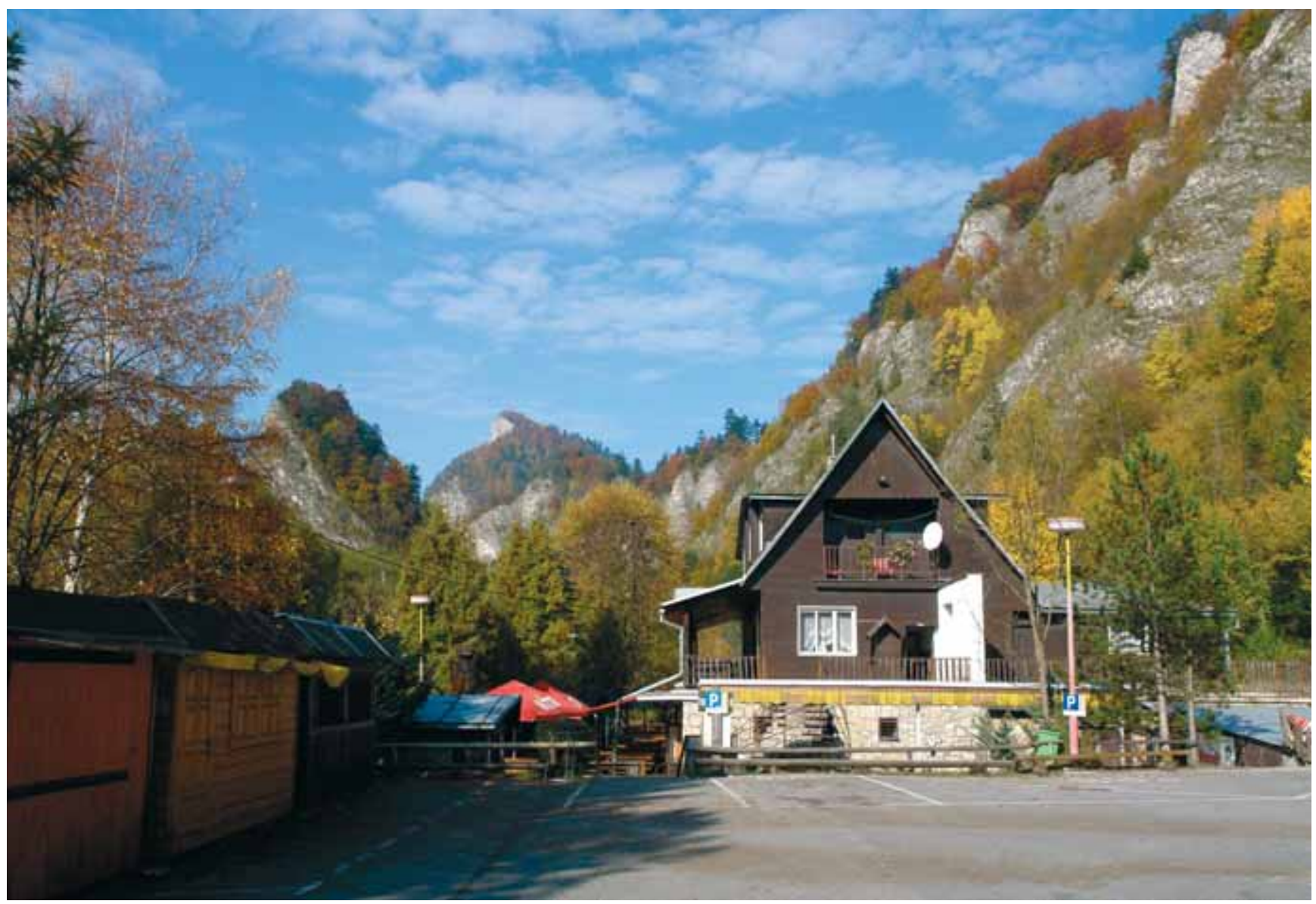

Fig. 8. The Leśnica valley, photo J. Golonka 


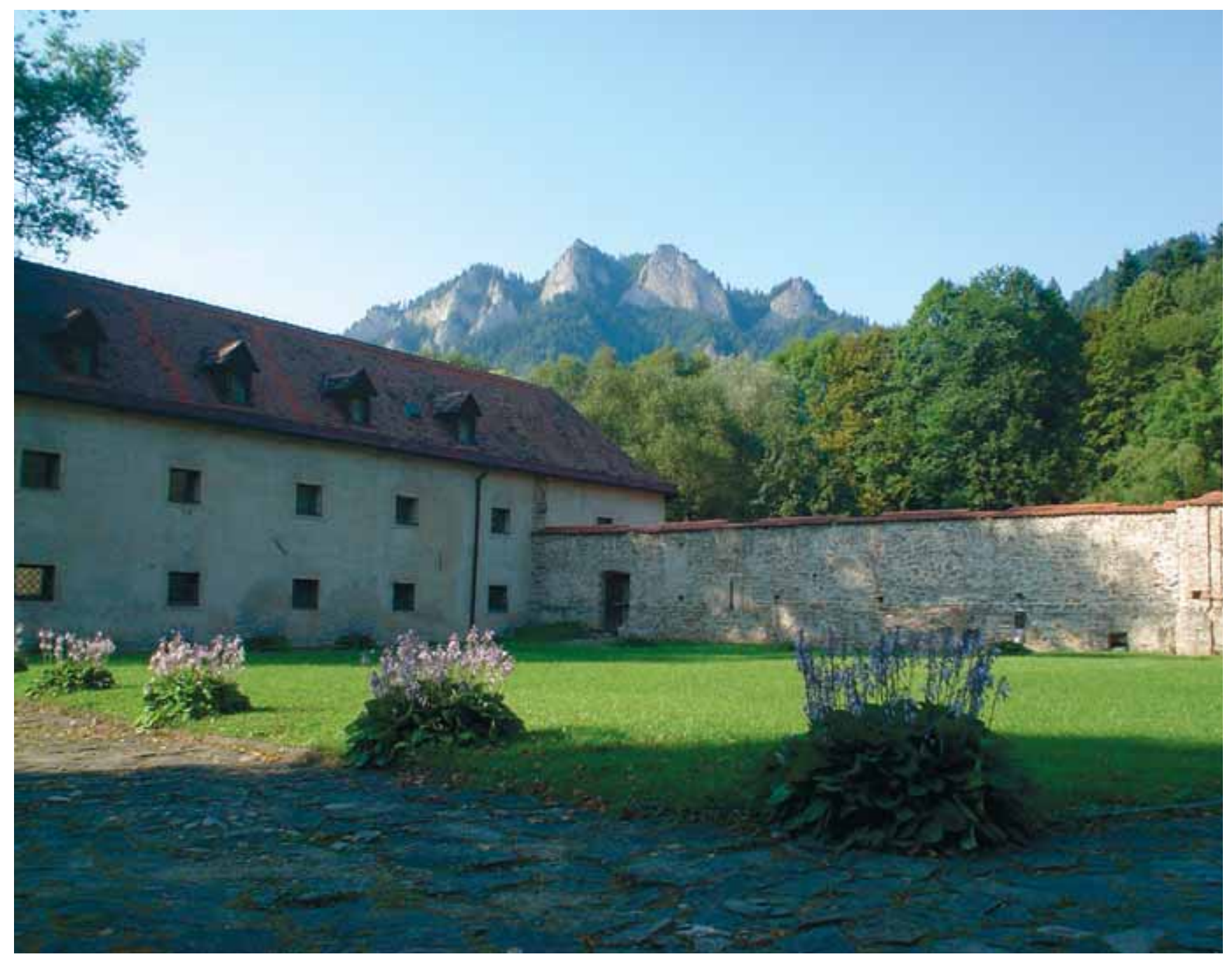

Fig. 9. The Červený Kláštor (Red Monastery) with a magnificent view on the Trzy Korony (Three Crowns) Mountain, photo J. Golonka

Faulting and uplifting played a tremendous role during the Neogene tectonic evolution. Dense and regular fault net is one of the characteristic features of the Carpathians. Brittle faults, mainly strike-slips in combination with other dynamical tectonic boundaries allowed propagation of individual detached blocks to the realm of the future Carpathian region (Golonka et al., 2005). At least some of the faults were still active during Quaternary time (Baumgart-Kotarba, 1996, 2001; Zuchiewicz et al., 2002). The studies of the 1995 earthquake (Baumgart-Kotarba, 2001 and references therein) show the good agreement of focal model with the tendencies of vertical crustal movements. The recent vertical movement in the area are up to $+0.5 \mathrm{~mm}$ per year (Vanko, 1988; Vass, 1998). During the fault-related uplift Dunajec River was cutting through the competent Jurassic-Early Cretaceous cherty limestones forming the magnificent cliffs of the gorge.

\section{The Palenica Mountain}

Palenica Mountain (722 m asl) is popular place among visiting tourists. It is located in the Małe Pieniny Mountains, south-east of Szczawnica town. It belongs to the Grajcarek Unit of the Pieniny Klippen Belt (Borecka et al., 2013). The mountain is built mostly by rocks originated in basin during the Late Cretaceous-Paleocene time. They are distinguished as Malinowa and Jarmuta formations. The Malinowa Formation constitutes the variegated (red, green, grey) shales with rare thin sandstone layers (of flysch type). The deposits of the younger Jarmuta Formation dominate in Palenica Mountain and form higher parts of the mountain. These deposits are represented mainly by thick-bedded muscovite sandstones and conglomerates interbedded by thin gray shales. The small exposures of these rocks occur in the top area and along the tourist trail. The extensive, relatively shallow landslide is in the northern slope (Radwanek-Bąk et al., 2009). It developed on the substructure of variegated shales of the Malinowa Formation. This landslide is still active and well visible due to its characteristic morphology.

Presently the Palenica Mountain is frequently visited by tourists. This is a great spot for hiking (yellow-marked tourist trail) and biking. The mountain top is available by the chairlift. This peak is particularly valuable because of the unique panorama of the Pieniny Mountains (Fig. 10) and Beskid Sądecki Mountains ranges. The lodge Groń and other gastronomical objects support the tourism. The ski slopes on Palenica Mountain are very popular during winter season. 


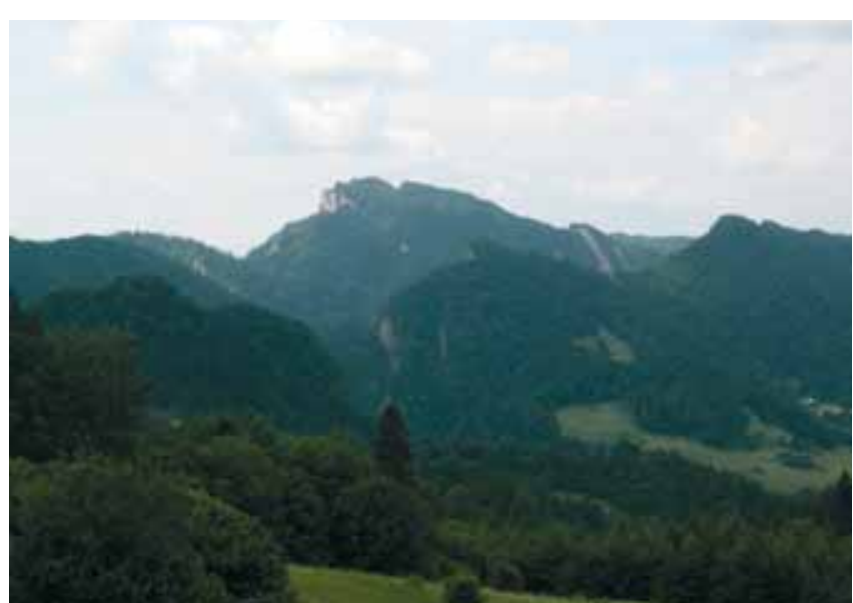

Fig. 10. The Trzy Korony (Three Crowns) Mountain - view from Palenica Mountain, photo A. Waśkowska

\section{The Zawiasy area}

The Zawiasy klippe is situated between Szczawnica and Krościenko towns, in the western bank of Dunajec River. This is relatively big klippe formed by Mesozoic limestones. The lithological inventory of the Zawiasy Klippe resembles the Branisko Succession (Birkenmajer, 1977,1979; Golonka, Krobicki, 2007). Strata in the klippe are in overturned position. The uppermost Jurassic-Lower Cretaceous Maiolica (=Biancone) type cherty limestones, belonging to the Pieniny Limestone Formation, prevail in the klippe (Fig. 11). They are representing by thin-to medium bedded white-grey hard limestones containing the variable quantity of silica and containing cherts. The Hedbergella microfacies (Golonka, Sikora, 1981) were distinguished in the uppermost part of these limestones what corresponds with the Albian age of top deposits. Partly cherty limestones occur here as a breccias form. The Albian-Cenomanian dark calcareous shales interbedded by cherty limestones of the Kapuśnica Formation and the Cenomanian-?Campanian calcareous deposits of the Jaworki Formation and end of the Zawiasy klippe section. The Jaworki Formation contains Scaglia Rossa-type rocks built of the thin-bedded very characteristic variegated (multicolored) pelagic limestones and marls, typical for the Late Cretaceous sedimentation of the Alpine oceans. The deposits of the Jurassic Skrzypne Shale Formation and Podzamcze Limestone Formation are known from Zawiasy klippe and constitute small fragment of this rock (Birkenmajer, 1979). The deposits in Zawiasy klippe are strongly tectonically deformed, presently form of different types of folds.

According to new paleogeographic reconstruction, the rocks built the Zawiasy klippe are the fragments of the Magura Basin incorporated into the Pieniny Klippen Belt (Golonka, 2006; Golonka, Krobicki, 2007). These fragments represent deposits origin on the area located between Czorsztyn Ridge and deeper part of the Magura Basin. These basins belonged to the western part of the Tethys Ocean. Presumably the rocks of the Zawiasy klippe could represent the Jurassic-Cretaceous age slope deposits of the Magura Basin and this hypothesis will be distinguished. The Scaglia Rossa-type rocks are connected with pelagic sedimentation during the latest episode of evolution of the Pieniny Klippen Basin (Birkenmajer, 1977, 1986). Interesting are the cherty limestones breccias, which correspond to breccias from the Czorsztyn Succession (Birkenmajer, 1977, 1986; Golonka, Krobicki, 2001; Golonka, 2006). These breccias are probably the effect of extensive gravitational faulting, which took place especially during and Neo-Cimmerian (Late Jurassic-Early Cretaceous) movements. These movements are presumably connected with initial stages of subduction of the oceanic crust of the Pieniny Klippen Belt Basin (Birkenmajer, 1986; Golonka, Krobicki, 2001, 2007; Golonka et al., 2005). It could be also interpreted as an effect of eustatic events (Michalík, Reháková, 1995) related with the global plate reorganization during Tithonian-Berriasian time (Jurassic-Cretaceous transition) what is result of the Tethyan Neo-Cimmerian tectonic activities (Golonka et al., 2003, 2005; Golonka, Krobicki, 2007).

The younger flyschoidal facies of the uppermost Cretaceous-Paleocene Jarmuta Formation accompanied calcareous rocks of the Zawiasy Klippe. They constitute surroundings for this klippe which has probably olistolithic origin. The Jarmuta Formation is represented by clastic rocks in which prevail sandstones and conglomerates interbedded by shales. It developed as submarine turbiditic wedges, fans and canyon fills during this syn-orogenic stage of the Pieniny Klippen Basin development (Birkenmajer, 1986).

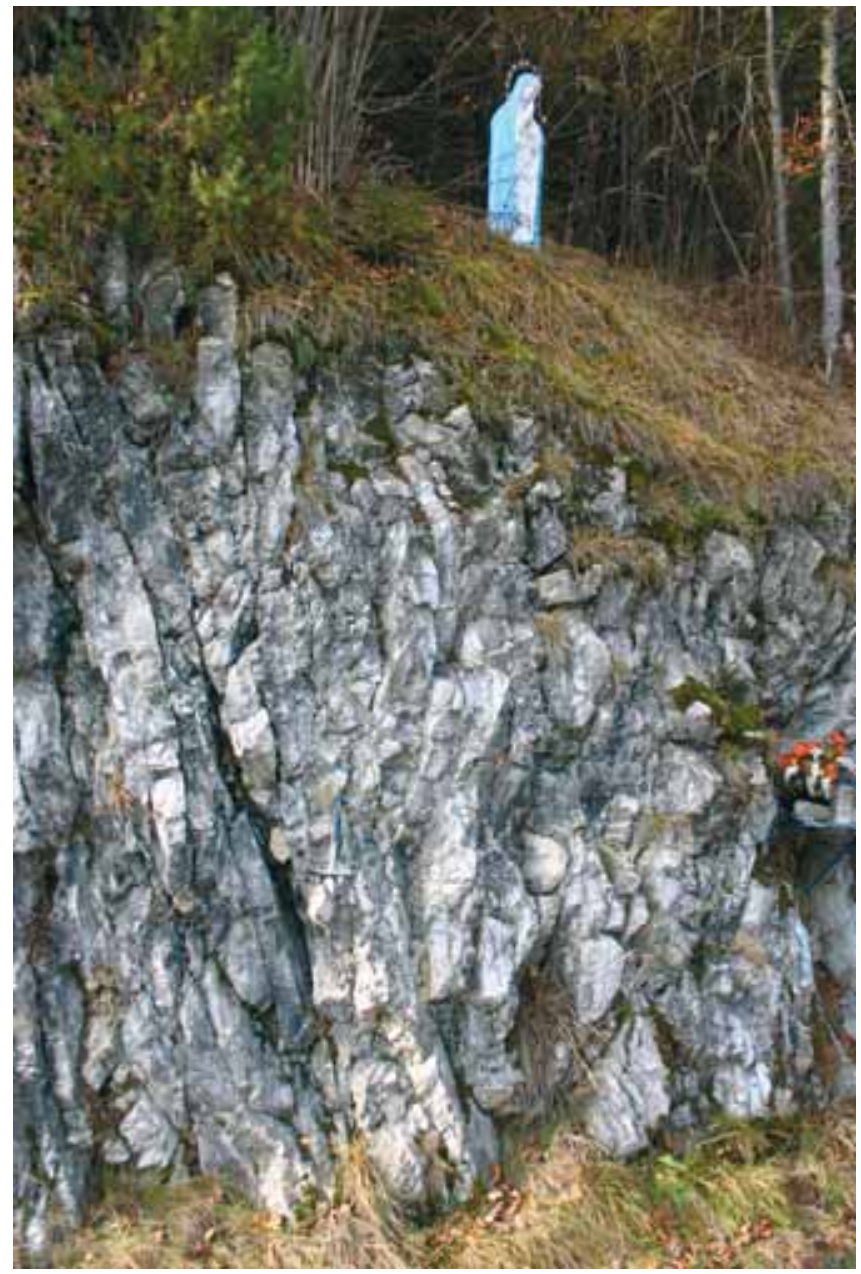

Fig. 11. The Pieniny Limestone Formation in Zawiasy klippe, photo M. Krobicki 


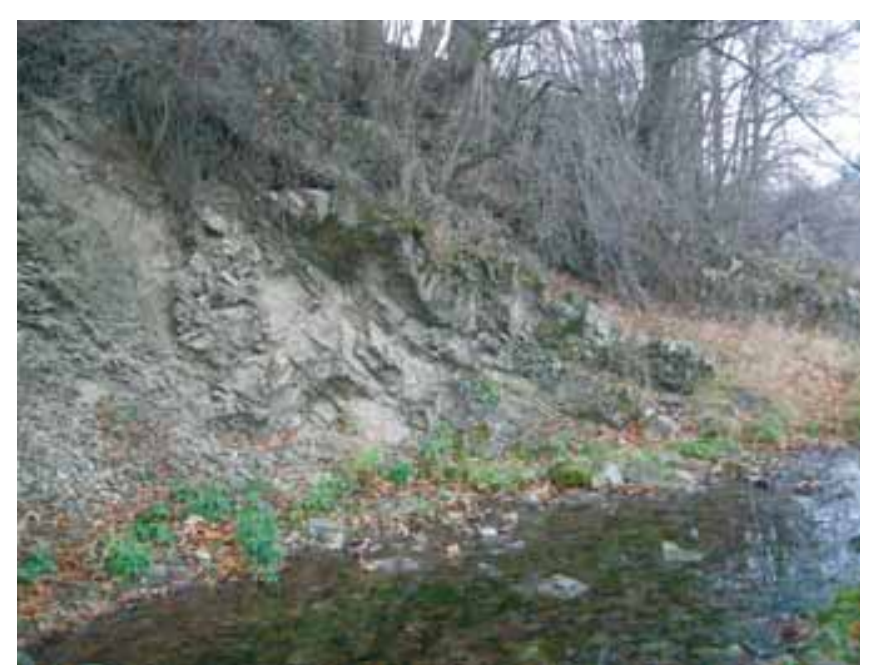

Fig. 12. The flysch of the Krynica Zone of the Magura Nappe exposed in Dunajec River, next to Zawiasy klippe, photo A. Waśkowska

The numerous outcrops of the younger Magura Nappe deposits are available here in Dunajec riverbed (Fig. 12). The best outcrops are close to the Zawiasy klippe, next to the St. Kinga Chapel, Zarzecze Formation of the internal Krynica Zone is exposed. This formation consists here from medium-bedded sandstones interbedded by shales. The submarine slump deposits with plastically deformed shaly clasts occur in this outcrop. The presence in this section of the Ląckotype marls is unusual. Ypresian-early Lutetian age of this deposits was estimated based on foraminifera (Golonka, Waśkowska, 2014).

Zawiasy Klippe which is covered by a rare and protected species of plants, and outcrops of Magura Nappe in Dunajec River are easily achievable by car or by foot. Along geosites runs the road, the last fragment of this road is close for automobile traffic. Zawiasy Klippe is situated across the Pienińska Karczma, constructed in typical Polish highland architectural style and offers the specialties typical for the Pieniny Mts. region.

\section{The Bryjarka Mountain}

The Bryjarka Mountain (679 m asl) is located northeast from Szczawnica town. It belongs to the Beskid Sądecki Mts. It is formed by the magmatic, subvolcanous hypabyssal intrusion cutting the sedimentary flysch deposits (Szczawnica Formation and Piwniczna Sandstone Member of the Magura Formation) belonging to the Krynica Zone of the Magura Nappe. The magmatic intrusion has a dyke character. Magmatic processes in Peri-Pieniny area are connected with Middle Miocene (Sarmatian) time (Birkenmajer et al., 1987; Birkenmajer, 2003) and formed so-called Pieniny Volcanic Arc (Birkenmajer, 2003; Birkenmajer et al., 2004) and have been radiometricaly dated here as 12.1-13.3 Ma old (Birkenmajer, Pécskay, 1999). The good outcrops are placed on the mountain's top, next to the huge iron cross (Fig. 13). The thickness of dyke is about $150 \mathrm{~m}$. It is built of amphibolitic andesite (microdiorite), which contain up to $5 \mathrm{~mm}$ plates of euhedral plagioclase and elongated but little smaller phenocrysts of amphibole set in matrix, built of partly recrystallized volcanic glass containing quartz, calcite, amphibole, plagioclase, chlorite, apatite and magnetite (Birkenmajer, 1957; BakunCzubarow, Białowolska, 2004 and papers cited therein). The joint, visible within the dike rocks originated as an effect of cooling of andesite magma. The andesites were partially altered by acidic mineral waters. The typical "gołoborze" or stone sea is located below the mountain top (Birkenmajer, 1979; Vončina et al., 2014). It originates during the weathering of the andesitic rocks. The andesitic rubbles contain $10-15 \mathrm{~cm}$ wide blocks. The stone sea area is small, gathering of the andesitic locks occupy about $100 \mathrm{~m}^{2}$. During the interwar period the andesites were mining in Bryjarka Mountain. The Bryjarka Mountain is situated near the spa's center and easily accessible by the yellow touristic trail. The walk takes about half of hour. Its top offers the magnificent panorama, which includes Szczawnica with the nearby Szlachtowa village and the range of Małe Pieniny in the background. The yellow trail leads from the Bryjarka toward the nearby mountain lodge "Chata pod Bereśnikiem". It is frequented by tourists offering the pleasant atmosphere, magnificent view and traditional Polish cuisine reasonably priced.

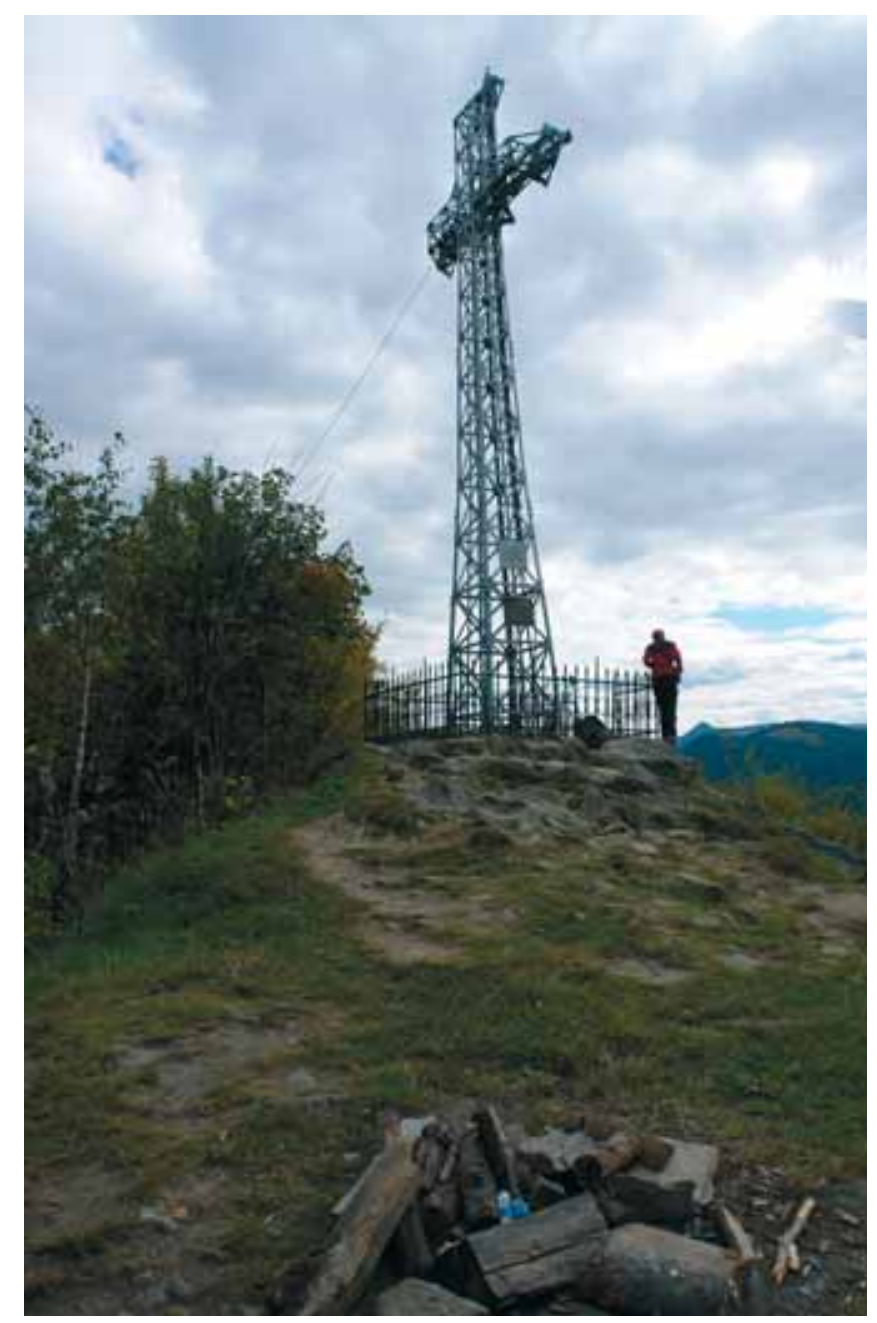

Fig. 13. The iron cross standing on the andesitic rocks of the Bryjarka Mountain, photo J. Golonka 


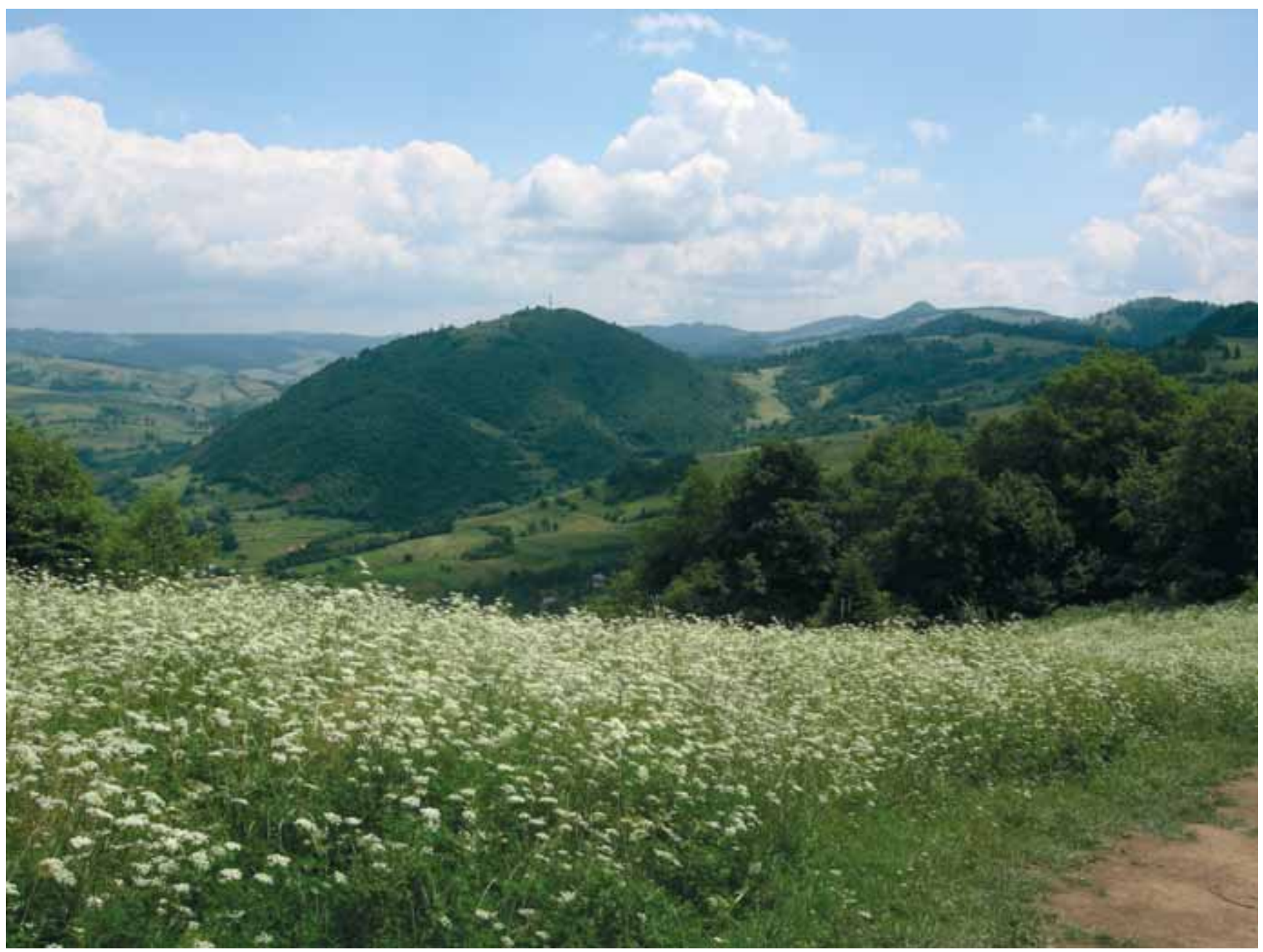

Fig. 14. The Jarmuta Mountain - view from Palenica Mountain, photo A. Waśkowska

\section{The Jarmuta Mountain}

The Jarmuta is the distinctive mountain in Małe Pieniny range with two culminations Jarmuta (794 m asl) and Czuprana (777 m asl) (Fig. 14). It is located close to the Malinowa hamlet within the eastern part of Szczawnica town.

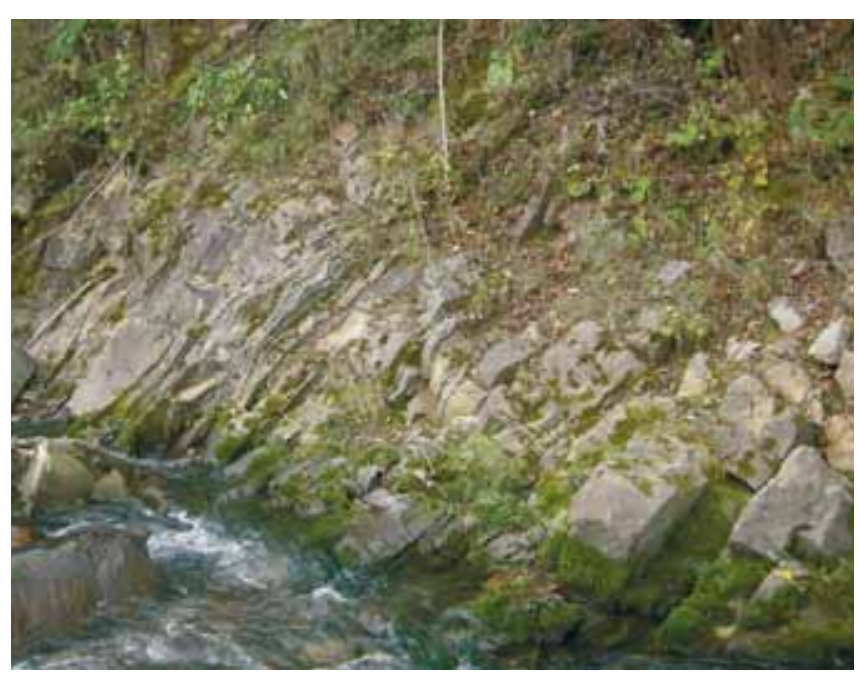

Fig. 15. The Jarmuta Formation in Grajcarek valley, below the Jarmuta Mountain, photo A. Waśkowska
Jarmuta Mountain is built by the Cretaceous-Paleocene deposits of the Malinowa and Jarmuta formations (Birkenmajer, 1979; Bartuś, Kuś, 2010 and papers cited therein). This area is locus typicus for both formations, here are the stratotype sections. The Malinowa Formation consists of characteristic variegated (multicolored - red, green, grey) partly marly shales. The rich foraminiferal assemblages are known from these deposits. The rare interbeddings of very-thin bedded sandstones are present within shales. The deposits of Jarmuta Formation constitute main rock mass in the mountain. They represent typical flysch rocks. The thick- and medium bedded calcareous sandstones are interbedded by thin layers of marly shales grey in color. These rocks are exposed in many slope outcrops in the Jarmuta Mountain, additionally good exposures are in Grajcarek River bed at the foot of the mountain (Fig. 15).

The intrusive magmatic rocks occur among Cretaceous deposits and are connected with Miocene volcanic activity in this region (Birkenmajer et al., 1987 and papers cited therein), radiometrically dated as 11.1-11.6 Ma (Birkenmajer, Pécskay, 1999). Małoszewski $(1958,1962)$ noted 23 intrusions build from andesites within Jarmuta Mountain. The thickest intrusion has $100 \mathrm{~m}$. The andesitic rocks influence the magnetic field. The magnetic anomaly occurs in this area (Małoszewski, 1958). The andesites were mined in the Malinów quarry, which is located in the northeast slope of the mountain (Figs 16, 17). 


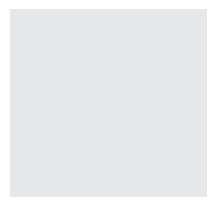

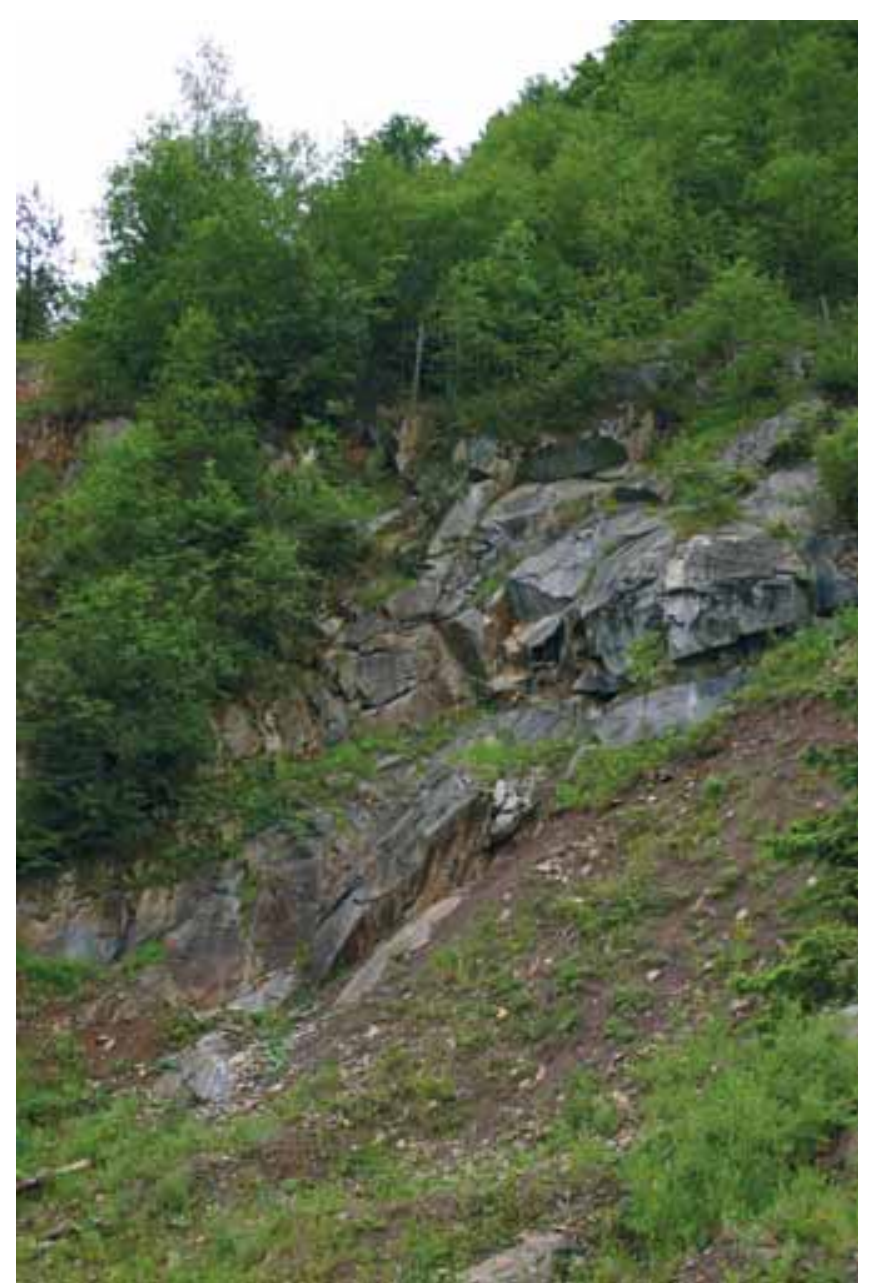

Fig. 16. The Malinów quarry in Jarmuta Mountain, photo M. Krobicki

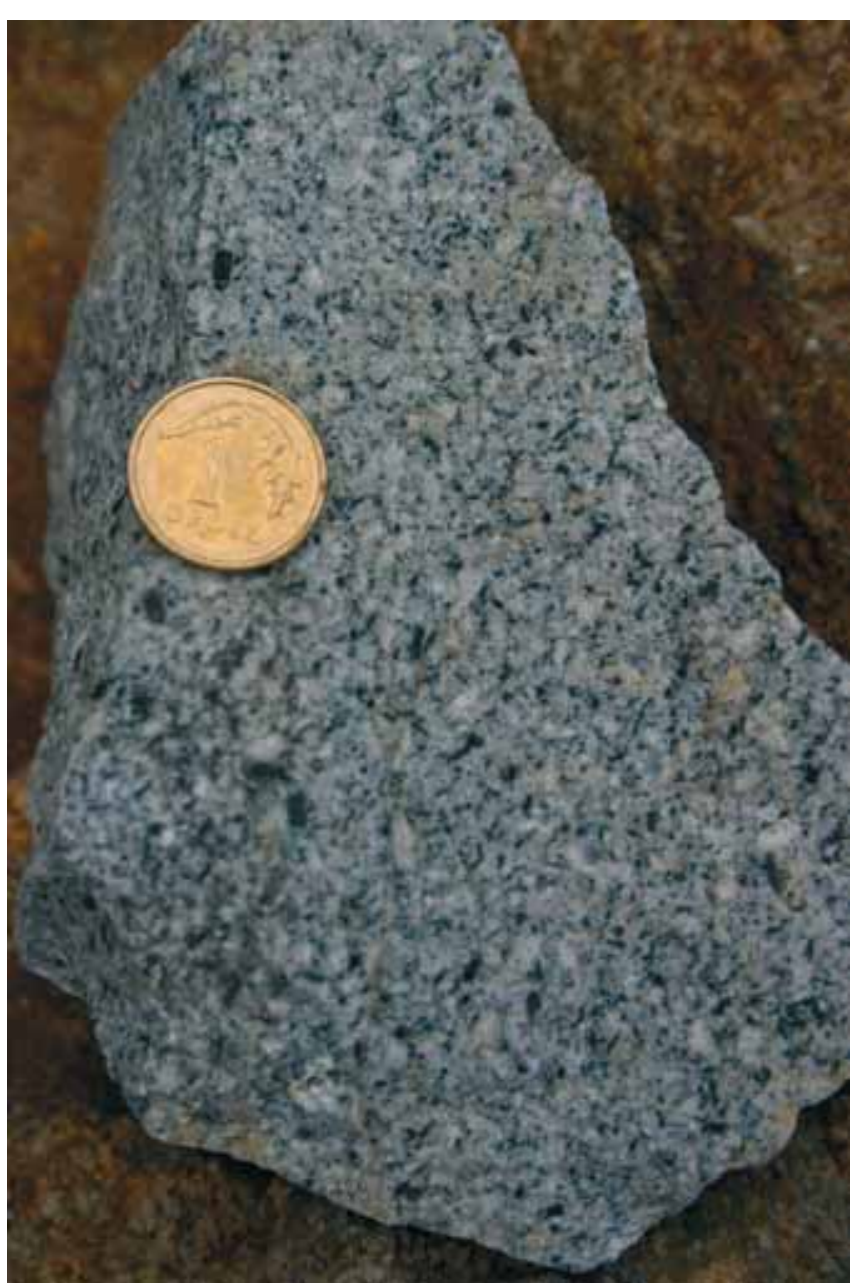

Fig. 17. The andesites from Jarmuta intrusion, photo M. Krobicki
The andesitic mining lasted to 70 years of the XX century. The xenoliths of sandstones are visible in this quarry within andesitic body. The contact zone of magmatic rocks with hosting sedimentary rocks metamorphosed within this contact aureole is well exposed here. The disintegrated andesite blocks constitute the small stone sea which is located on the northern slope of Jarmuta Mountain in place called "Pod Bukami” (Radwanek-Bąk et al., 2009). The ore mineralization was the result of hydrothermal fluids activity connected with the volcanic process. The mineralization of limonite, with subordinate galena, pyrite, pyrrhotite, quartz, apatite, gypsum, calcite chalcopyrite, bornite, covellite, malachite, azurite, cerussite, arsenopyrite, sphalerite and magnetite, as well as native metals $(\mathrm{Au}, \mathrm{Ag}, \mathrm{Cu}, \mathrm{Hg}$ ) is known from Jarmuta rocks (e.g. Małkowski, 1918; Wojciechowski 1950, 1955; Birkenmajer et al., 2004; Jurewicz et al., 2007; and papers cited therein). The ore enrichment caused that the Jarmuta Mountain was the main mining area in Pieniny region. The exploitation was performed here at least from XVII century (Birkenmajer, 1979; Birkenmajer et al., 2004; Jurewicz et al., 2007; Bartuś, Kuś, 2010; and papers cited therein). The miners searched mainly for gold and silver. The two levels of adits known as Bania w Jarmucie remaining in eastern slope of the mountain document historical mining activity (Bartuś, Kuś, 2010). The total length of adits reaches around $122 \mathrm{~m}$.
The Jarmuta Mountain is easily available; the distance from the city center is $2 \mathrm{~km}$. The comfortable car parking places are located in the vicinity of Jarmuta. The Andrzejówka meadow (Polana) on the mountain top is the starting point for paragliders while the quads use trails at the foot of Jarmuta. The mountain top offers the magnificent panorama of the Beskid Sądecki and Pieniny mountains ranges. The tourist can get it. The Jarmuta Mountain top is recognizable by the characteristic TV relay and accesible by many local hiking paths.

\section{The Zaskalnik Waterfall}

One of the most beautiful and highest waterfalls within the Polish Outer Carpathians is located in the Szczawnica at Sewerynówka hamlet. Its high is estimated for $4 \mathrm{~m}$ (Fig. 18). The Zaskalnik Waterfall, developed in the bedrocks on Sopotnicki stream, is situated close to the road, slightly below the "Czarda" restaurant (Słomka, ed., 2012).

The flysch rocks belonging to the Paleogene deposits of the Magura Nappe are exposed in the Sopotnicki stream valley in Sewerynówka hamlet, Beskid Sądecki Mountains, Poprad Landscape Park. The waterfall creation is related to the change of lithology. The waterfall's knickpoint is on the boundary between two Magura Nappe stratigraphic units: Magura and Zarzecze formations. These deposits are 


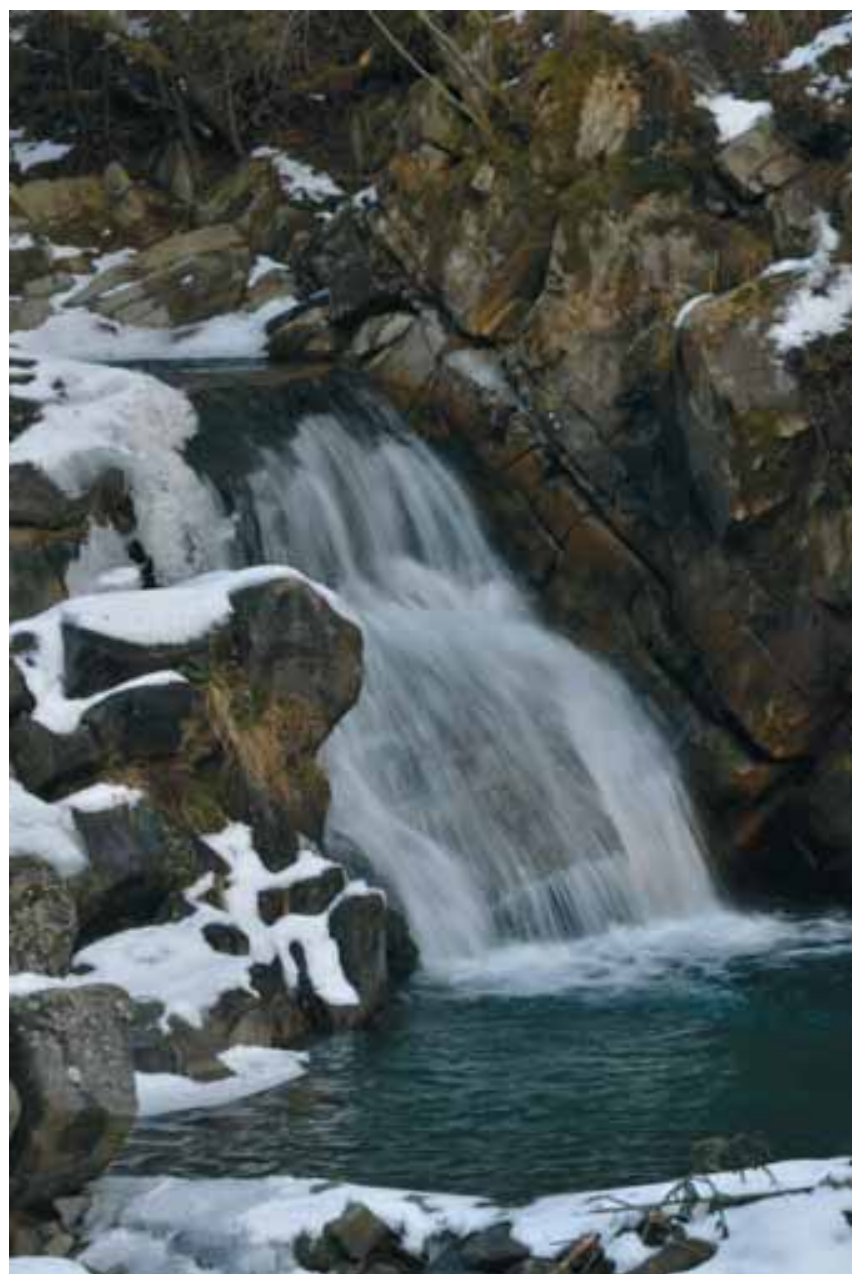

Fig. 18. The Zaskalnik Waterfall, photo M. Doktor

Eocene in age and represent deep water environment. The sedimentation took place about 40-35 Ma in the northeastern part of Alpine Tethys Ocean, which is known as Magura Basin.

The Piwniczna Sandstone Member rocks of the Magura Formation build the upper part of the waterfall. They are represented mostly by thick- and very thick bedded amalgamated sandstones occurring in complexes which are interbedded by thin layers of grey shales. Zarzecze Formation occur in the base of waterfall. It consists of shaly-sandy flysch deposits, where dominated grey-greenish shales are interbedded by thin- to medium-bedded laminated sandstones. The boundary sequence is perfectly visible within the Zaskalnik waterfall limits.
The flysch layers are tectonically deformed, dipping $45^{\circ}$ northward (Słomka et al., 2012). This position of rock is effect of the orogenic movements, which took place in Miocene time during formation of Carpathian arc.

The rocks of the Zarzecze Formation, dominated by soft shales, are much less resistant to mechanical erosion than sandy Magura Formation. The deep evorsion bowl was formed at the bottom of the Zaskalnik Waterfall, within the topmost part of the Zarzecze Formation deposits. The seeps of mineral water are connected with the boundary sequence.

Highly educational geological processes of water erosion, morphological form of stream and waterfall, as well as lithological development causes that the Zaskalnik Waterfall constitute unquestionable geotouristic object. It is accessible by car and on foot and this accessibility provides the real advantage of this object. The cars can use the small parking lot. The lack of any explanation board is the attraction's disadvantage. The bluemarked tourist trail goes along the road next to the waterfall. This trail starts in the center of Szczawnica town and leads to Przehyba (1175 m asl) and Radziejowa (1262 m asl) mountains, which constitute the main ridge of the Beskid Sądecki Mts.

\section{Conclusion}

Szczawnica town is an informal capital of the Pieniny Mountains. It's flourished mainly by mineral springs, which are used in balneology. By this reason Szczawnica is very popular for tourists as mountain spa, where different kind of natural values are fundamentals in progress of this town and propagation of walking, biking and skiing. Touristic offers are wider and wider and new disciplines of sports/resting are more popular. Geotourism is one of such new tourism branches. The knowledge of Geotourism is still increasing among numerous tourists. Szczawnica vicinity is full of such geotouristic attractions, which are perfect objects for better understanding of the history of our Earth and numerous geological processes, which „sculptured” its surface, especially very complicated geological story of the Pieniny Klippen Belt. Therefore, in this paper, the most characteristic outcrops/geological monuments which surrounded Szczawnica spa are presented with short geological/geomorphological remarks about their origin, development and significance in natural sciences.

\section{Acknowledgment}

Paper was prepared thanks to the financial support of AGH grant no 11.11.140.173.

\section{References}

Bakun-Czubarow N., Białowolska A., 2004. Origin of amphibole rock enclaves in the Bryjarka andesites, Pieniny Mountains, West Carpathians. Prace Specjalne Polskiego Towarzystwa Mineralogicznego, 24 79-83.

Bartuś T., Kuś T., 2010. Szlachtowski obszar eksploatacji kruszców, jako element projektowanego geoparku "Pieniny". Geoturystyka, 21: 35-58.

Baumgart-Kotarba M., 1996. On origin and age of the Orava Basin, West Carpathians. Studia Geomorphologica Carpatho-Balcanica, 30: 101-116.

Baumgart-Kotarba, M., 2001. Continuous tectonic evolution of the Orava basin from Late Badenian to the present-day. Geologica Carpathica, 52: 103-110. Birkenmajer K., 1957. Dajki andezytowe góry Bryjarki w Szczawnicy. Przeglad Geologiczny, 2: 62-65.

Birkenmajer, K., 1977. Jurassic and Cretaceous lithostratigraphic units of the Pieniny Klippen Belt, Carpathians, Poland. Studia Geologica Polonica, 45: 1-158.

Birkenmajer K., 1979. Przewodnik geologiczny po pienińskim pasie skatkowym. Wydawnictwa Geologiczne, Warszawa. 
Birkenmajer K., 1986. Stages of structural evolution of the Pieniny Klippen Belt, Carpathians. Studia Geologica Polonica, 88: 7-32.

Birkenmajer K., 2003. Post-collisional Late Middle Miocene (Sarmatian) Pieniny Volcanic Arc, Western Carpathians. Bulletin of the Polish Academy of Sciences, Earth Sciences, 51: 79-89.

Birkenmajer K., 2006. Przełom Dunajca w Pieninach - fenomen geologiczny. Pieniny-przyroda i czlowiek, 9: 9-22.

Birkenmajer K., 2007. The Czertezik Succession in the Pieniny National Park (Pieniny Klippen Belt, West Carpathians): stratigraphy, tectonics, palaeogeography. Studia Geologica Polonica, 127: 7-50.

Birkenmajer K., Pécskay Z. 1999. K-Ar dating of the Miocene andesite intrusions, Pieniny Mts., West Carpathians. Bulletin of the Polish Academy of Sciences, Earth Sciences, 47: 155-169.

Birkenmajer K., Delitala M.C., Nicoletti M., Petrucciani C., 1987. K-Ar dating of andesite intrusions (Miocene), Pieniny Mts., Carpathians. Bulletin of the Polish Academy of Sciences, Earth Sciences, 35: 11-19.

Birkenmajer K., Pécskay Z., Szeliga W., 2004. Age relationships between Miocene volcanism and hydrothermal activity at Mt Jarmuta, Pieniny Klippen Belt, West Carpathians, Poland. Studia Geologica Polonica, 123: 279-294.

Borecka A., Danel W., Krobicki M., Wierzbowski A., 2013. Pieniński Park Narodowy-mapa geologiczno-turystyczna, skala 1: 25 000. Państwowy Instytut Geologiczny, Państwowy Instytut Badawczy, Warszawa.

Chrustek M., Golonka J., 2005. Carpathian tectonics in the making - deformations and earthquakes in the Stare Bystre area (southern Poland). In: Doktor M., Waśkowska-Oliwa A. (eds), Geotourism - new dimensions in XXI century tourism and chances for future development. 2nd Internation Conference Geotour 2005, 22-24 September, Kraków: $16-18$.

Chrustek M., Golonka J., Janeczko A., Stachyrak F., 2005. Geological characterisation of the Krynica Subunit in the vicinity of Krościenko on the Dunajec river (Magura Nappe, Outer Flysch Carpathians). Geologia, 31: 127-144.

Cieszkowski M., Golonka J., Krobicki M., Ślączka A., Oszczypko N., Waśkowska A., Wendorff M., 2009. The Northern Carpathians plate tectonic evolutionary stages and origin of olistoliths and olistostromes. Geodinamica Acta, 22: 1-26.

Golonka J. 2006. Field trip A - From Tethyan to Platform Facies. Stop A6 Sromowce-Kąty-Dunajec River Boat trip (rafting). In: Wierzbowski A., Aubrecht R., Golonka J., Gutowski J., Krobicki M., Matyja B.A, Pieńkowski G., Uchman A. (eds), Jurassic of Poland and adjacent Slovakian Carpathians. Field trip guidebook. $7^{\text {th }}$ International Congress on the Jurassic System, 6-18 September 2006, Kraków, Poland: 42-46.

Golonka J., Cieszkowski M., Waśkowska A., Krobicki M., Ślączka A., 2010. Olistostromes of the Pieniny Klippen Belt, Northern Carpathians. Geologica Balcanica, 39: 137-138.

Golonka J., Doktor M., Miśkiewicz K., Krobicki M., Słomka T., 2014. Selected geosites within a proposed new trans-border Pieniny Geopark (Polish-Slovakian). Acta Geoturistica, 5 (2014), 2: 46-63.

Golonka J., Krobicki M., 2001. Upwelling regime in the Carpathian Tethys: a Jurassic-Cretaceous palaeogeographic and palaeoclimatic perspective. Geological Quarterly, 45: 15-32.

Golonka J., Krobicki M., 2007. The Dunajec River rafting - one of the most interesting geotouristic excursions in the future trans-border PIENINY Geopark. Geoturystyka, 10: 29-44.

Golonka J., Krobicki M., Waśkowska A., Cieszkowski M., Ślączka A., 2015. Olistostromes of the Pieniny Klippen Belt, Northern Carpathians. Geological Magazine, 152, 2: 269-286.

Golonka J., Krobicki M., Tłuczek D., 2005. Field Trip: Pieniny Klippen Belt and Polish Outer Carpathians. Geotourism - new dimensions in XXI century tourism and chances for future development. 2nd International Conference Geotour 2005: 22-24.
Golonka J., Krobicki M., Oszczypko N., Ślączka A., Słomka T. 2003. Geodynamic evolution and palaeogeography of the Polish Carpathians and adjacent areas during Neo-Cimmerian and preceding events (latest Triassic-earliest Cretaceous). In: McCann T., Saintot A. (eds), Tracing Tectonic Deformation Using the Sedimentary Record. Geological Society, London, Special Publications, 208: 138-158.

Golonka J., Sikora W., 1981. Microfacies of the Jurassic and Lower Cretaceous sedimentarily thinned deposits of the Pieniny Klippen Belt in Poland. Biuletyn Instytutu Geologicznego, 31: 7-37.

Golonka J., Waśkowska A., 2014. Paleogene of the Magura Nappe adjacent to the Pieniny Klippen Belt between Szczawnica and Krościenko (Outer Carpathians, Poland). Geology, Geophysics and Environment 4: 359-376.

Jurewicz E., Hercman H., Nejbert K., 2007. Flowstone-like calcite in the andesite of Jarmuta Mt. - dating the Holocene tectonic activity in the vicinity of Szczawnica (Magura Nappe, Outer Carpathians, Poland). Acta Geologica Polonica, 57: 187-204.

Małkowski S., 1918. Le métamorphisme du contact et le filon mettalifère dans le mont Jarmuta près de Szczawnica. Sprawozdania Towarzystwa Naukowego, 11: 681-698.

Małoszewski S., 1958. Anomalie magnetyczne w Pieninach. Prace Muzeum Ziemi, 1: 105-113.

Małoszewski S., 1962. Magnetic measurement of andesite occurrence in the vicinity of Szczawnica. Prace Geologiczne Polskiej Akademii Nauk, 10: $1-140$.

Michalík J., Reháková D., 1995. Sedimentary records of Early Cretaceous tectonic activity in the Alpine-Carpathian region. Slovak Geological Magazine, 2: 159-164.

Radwanek-Bąk B., Bąk B., Kopciowski R., Laskowicz I., Szeląg A., Wójcik A., 2009. Georóżnorodność i atrakcje geoturystyczne województwa małopolskiego. Wydawnictwo Kartograficzne „Compass”, Kraków.

Słomka T. (ed.), 2012. Katalog obiektów geoturystycznych $w$ obrębie pomników i rezerwatów przyrody nieożywionej. AGH Akademia Górniczo-Hutnicza, Wydział Geologii, Geofizyki i Ochrony Środowiska, Katedra Geologii Ogólnej i Geoturystyki.

Ślączka A., Kruglow S., Golonka J., Oszczypko N., Popadyuk I., 2006. The General Geology of the Outer Carpathians, Poland, Slovakia, and Ukraine. American Association of Petroleum Geologists, Memoir, 84: 221-258.

Tłuczek D., 2004. Pozycja geologiczna paleogeńskich wapieni organogenicznych oraz zlepieńców i piaskowców organodetrytycznych rejonu Lipnika (Pieniny na potudnie od Szczawnicy - kartowanie detaliczne, mikrofacje, aspekt geoturystyczny). Unpublished Mr. Thesis. Archiwum ING UJ.

Vanko J., 1988. Mapa recentných vertikálnych pohybov Západných Karpát na Slovensku ore epochu 1952-1977. Geodetický a kartografický obzor, Bratislava, 34/76: 216-222.

Vass D., 1998. Neogene geodynamic development of the Carpathian arc and associated basins. In: Rakús M. (ed.), Geodynamic development of the Western Carpathians. Geological Survey of Slovac Republic, Bratislava, Dionýz Štúr Publishers: 155-158.

Vončina G., Wawrzczak M., Betleja L., Kozik J., Kościelniak J., Kościelniak R., Chachuła P., Bryjarka bill in Szczwnica (Beskid Sąecki Mts, Western Carpathians, Poland) - a natural and cultural focus, Acta $\mathrm{Mu}-$ sei Silesiae, Scientiae Naturales, The Journal of Silesian Museum in Opava, 63: 111-122, 2014.

Węglarz B.A., 2011. Spacerkiem po starej Szczawnicy. Oficyna Wydawnicza Rewasz, Piastów.

Wojciechowski J., 1950. Native gold and associated ore minerals of the mineral vein near Szczawnica, Pieniny Mts., Western Carpathians. Acta Geologica Polonica, 1: 143-149.

Wojciechowski J., 1955. Ore veins near Szczawnica, Pieniny Mts., Western Carpathians. Biuletyn Instytutu Geologicznego, 101: 1-82.

Zuchiewicz W., Tokarski A.K., Jarosiński M., Márton E., 2002. Late Miocene to present day structural development of the Polish segment of the Outer Carpathians. EGU Stephen Mueller Special Publication Series, 3: 185-202. 